\title{
INTERACTION OF N-ACETYLNEURAMINIC ACID WITH SURFACE SILICON IN AQUEOUS SOLUTION WITH CARBOHYDRATES
}

\author{
L.M. Ushakova, E.M. Demianenko, M.I. Terets, V.V. Lobanov, M.T. Kartel \\ Chuiko Institute of Surface Chemistry, NAS of Ukraine, 17 General Naumov Str., \\ Kyiv03164, Ukraine e-mail: mva@gmail.comilushako
}

The aim of the work is to study interaction of $N$-acetylneuraminic acid (NANA) with the surface of ultrafine silica (UFS) with the participation of glucose and sucrose in aqueous solution at the supramolecular level by density functional theory method (exchange-correlation functional $B 3 L Y P$, basis set of 6-31G $(d, p)$.

The adsorption of $N$-acetylneuraminic acid, as well as individual carbohydrates (glucose and sucrose) on the hydrated surface of UFS in aqueous solution, was considered as a process of replacement of water molecules on the surface of silica by adsorbate molecules.

This work considers two schemes of carbohydrate molecule influence on adsorption of $N$ acetylneuraminic acid. According to the first scheme the interaction of the NANA molecule occurs with the silica-monosaccharide complex, according to the second scheme, the silica cluster interacts with the NANA-monosaccharide complex, where silica binds to the complex through the carbohydrate molecule.

The analysis of the calculated geometric and energy characteristics show that adsorption on the surface of silica, with hydration taken into account, is thermodynamically probable for the sucrose. The glucose molecule has a positive value $(+9.8$ and $+2.7 \mathrm{~kJ} / \mathrm{mol})$ is an unfavorable process in terms of thermodynamics regardless of the hydrating water cluster size. The $N$ acetylneuraminic acid molecule has a value of $-1.3 \mathrm{~kJ} / \mathrm{mol}$ for the reaction with five water molecules and $+0.9 \mathrm{~kJ} / \mathrm{mol}$ with eight water molecules.

It was found that the presence of sucrose on the silica surface in the aqueous solution weakens the hydration energy (i.e. it is easier to replace the cluster of water with the $N$ acetylneuraminic acid molecule from the surface of the modified adsorbent), which in turn promotes NANA adsorption on the silica surface. Therefore, scheme 1 is thermodynamically more likely than scheme 2.

This indicates that there is a mutual influence of substances in a mixture of NANA with carbohydrates on the interaction with silica in comparison with the interaction of substances with silica alone.

Keywords: ultrafine silica surface, adsorption of $\mathrm{N}$-acetylneuraminic acid, glucose, sucrose, supermolecular approximation, density functional method.

\section{Introduction}

To increase the selective properties of nanomaterial surface relative to the cell membrane, it is necessary to pre-modify it with biomolecules. The chemical modification of the surface of silica by carbohydrates, is a rather promising and chemically feasible method of obtaining such 
complexes. This is due to the fact that they have a high degree of chemical affinity for carbohydrate fragments of cell receptors. Although there is a number of difficulties in modifying the surface of carbohydrates due to peculiarities of the chemical structure of some carbohydrates and their interaction with the surface of ultrafine silica (UFS). It is important that modifier is selected so that the obtained complex will not damage the membrane later [1]. It is known that the outer surface of the membrane includes glycolipids, glycoproteins and oligosaccharide residues. N-acetylneuraminic acid (NANA) is a carbohydrate that forms their terminal residues and is part of gangliosides.

Some viruses (such as the flu virus) choose it as a receptor. $\mathrm{N}$-acetylneuraminic acid is also found in large quantities in metastatic cancer cells. To modify the surface of silica, it is advantageous to use biomolecules that are compatible with living systems, while the surface of silica is covered with hydroxyl groups, which under certain conditions can be replaced by other functional groups that play the role of adsorption centers of biomolecules.

NANA nanocomposites are used in animal husbandry (cryopreservation), for influenza treatment, for the detection of cancer cells, as well as for the delivery of drugs to affected cells.

D-glucose is a colorless crystalline substance with a sweet taste, well soluble in water. The glucose molecule can exist in two forms: $\alpha$-D-glucose and $\beta$-D-glucose. In aqueous solution, an equilibrium is established between several mutually transitional forms of D-glucose: $\alpha$ - and $\beta$ pyranose, $\alpha$ - and $\beta$-furanose and open aldehyde. In nature it occurs in the free state in mammals blood and plant sap, and is a part of various compounds ranging from sucrose, cellulose, starch and ending with some glycoproteins [1]. Glucose is the main source of energy for cells and tissues of the body. It is widely used in medicine as a part of blood substitute and anti-shock fluid.

Sucrose is a disaccharide that is most common in nature. It is a reserve energy carbohydrate that accumulates in plants. Sucrose is mostly used in microbiology and surfactants production [2, 3].

There is a list of studies stating that adsorption from the aqueous phase on the surface of silica of glucose, fructose, galactose, mannose [6-8], and $\mathrm{N}$-acetylneuraminic acid [5] is impossible.

Only for $\mathrm{N}$-acetylglucosamine and galactosamine adsorption on UFS is possible, which is explained by the presence of the amino group in the composition of their molecules [9]. During the adsorption of these monosaccharides $\equiv \mathrm{Si}-\mathrm{OH} \cdots \mathrm{NH} 2$ complex with a donor-acceptor nature is formed. The unshared electron pair of the amino group acts as a donor, and the proton of the silanol group acts as an acceptor. The binding energy formed during the adsorption of aminosaccharides is $30.8 \mathrm{~kJ} / \mathrm{mol}$. The adsorption isotherms of these aminosaccharides, according to the Giles classification, belong to the S3-type. Such isotherms are characteristic of the case when "the energy of interaction between the adsorbed molecules is greater than the energy of interaction between the molecule of the solute and the adsorbent" [10]. Depending on the concentration, adsorption can take the form of di-, tri-, tetra- or hexamers of aminosaccharides. This is also explained by the fact that adsorption on the surface of silica occurs in the form of clusters. Self-organization of aminosaccharides is carried out on the surface of the adsorbent due to carbohydrate-carbohydrate interactions. These assumptions are based on adsorption parameters.

The work 4 shows that the surface of UFS is able to adsorb sucrose from the aqueous phase, in accordance with the results of the process simulation. The adsorption isotherm has the S-shape. According to Parfitt and Rochester, this shape of the curve indicates the chain arrangement of the adsorbate molecules on the surface of the carrier. [11] Thus, we can assume that the surface of UFS contributes to the chain arrangement of sucrose molecules, i.e. the first layer on the surface of silica is first sorbed and only then polymolecular adsorption begins.

The amino group plays a significant role in the interaction of monosaccharides with silica. It was found that during the chromatographic separation of a mixture of carbohydrates on a silica carrier - silica gel, modified with an amine-containing compound (piperazine) having the group - 
$\mathrm{NH} 2$, they are separated by the number of monomers in the molecule. The amino group attached to the silica gel contributes to a higher content of carbohydrates that have more hydroxyl groups. We can see here that monosaccharides leave the column earlier than disaccharides and disaccharides earlier than trisaccharides. The overall configuration of the molecule has a significant effect on the retention time. Branched saccharide molecules leave the column earlier [11].

The retention time of seven monosaccharides and three disaccharides on mesoporous aminated silica (Silasorb SiNH2) (360 m2/g) was measured by liquid chromatography. Acetonitrile and water were used as the mobile phase [12]. It was illustrated that monosaccharides were less adsorbed than disaccharides. This is due to nonspecific dispersion forces which occure during adsorption process. When adsorbing monosaccharides on the aminated surface, there are factors that reduce adsorption, these are the features of their structure: the presence of $\mathrm{CH} 3$ groups (rhamnose), the right position of the $\mathrm{OH}$ group closest to the aldehyde (xylose), replacement of the aldehyde group with ketone (fructose).

Considering the adsorption of disacharides the following features of the structure that affect the reduction of adsorption energy should be noted: the proximity of the lactone oxygen atom to bridging oxygen (sucrose), while the factor of increasing adsorption energy is the trans position of the group - $\mathrm{CH} 2 \mathrm{OH}$ (lactose). It is assumed that the spatial structure of saccharide molecules can change under the action of adsorption forces, and their adsorption is influenced by solvent molecules such as water, if the adsorption occurs in aqueous solution. It has not been definitively established yet whether water molecules affect the adsorption of $\mathrm{N}$-acetylneuraminic acid and carbohydrates. Therefore, the aim of this work is to investigate the methods of quantum chemistry of the interaction of NANA with the surface of silica with the participation of glucose and sucrose in aqueous solution at the supermolecular level, i.e. with explicit consideration of water molecules as a solvent.

\section{Methods and objects of research}

The following models of carbohydrates are used in this work: monosaccharide - glucose in the most thermodynamically stable cyclic form of glucose [13] in the form of $\beta$-D-glucopyranose (Fig. 1, a), and disaccharide-sucrose shown in Fig. 1, b [14], which consists of residues of Dglucopyranose and D-fructofuranose interconnected by an oxygen bridge.
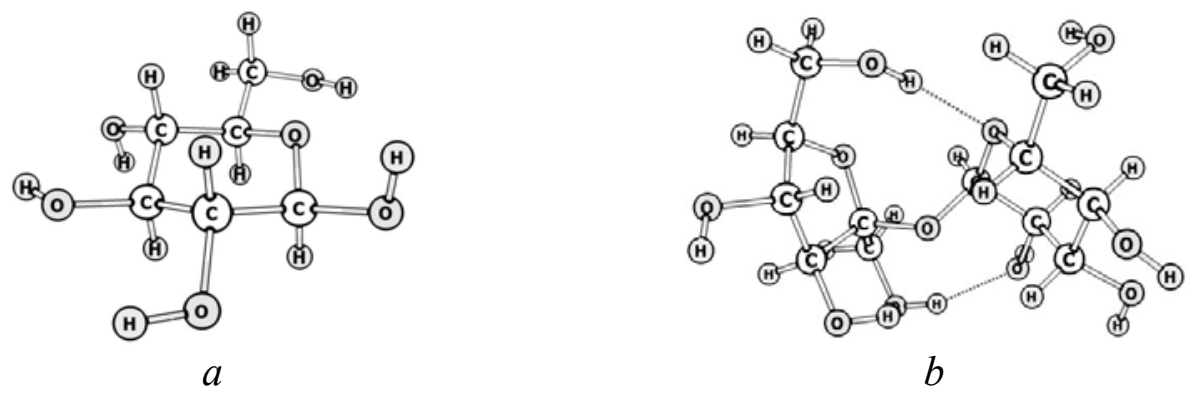

Fig. 1. Models: a - glucose models and, b-sucrose

A cluster consisting of 18 silicon-oxygen tetrahedra (Fig. 2, a) with $\mathrm{Si}_{18} \mathrm{O}_{48} \mathrm{H}_{24}$ gross composition, commensurate with the NANA molecule and the investigated saccharides was used as a model of silica surface. This model had been also used in our preceding works $[15,16]$ related to the study of the interaction of silica with monosaccharides and N-acetylneuraminic acid. It allowed us to compare the calculation results of the energy characteristics of the compounds studied in this work with similar values calculated in our works. The model of the molecular form of $\mathrm{N}$ acetylneuraminic acid is presented in Fig. 2, b. 


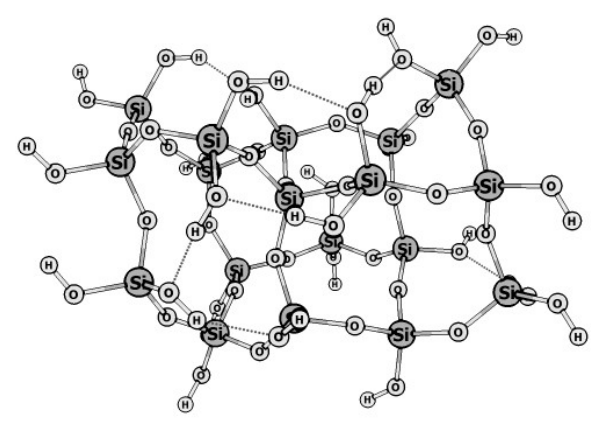

$a$

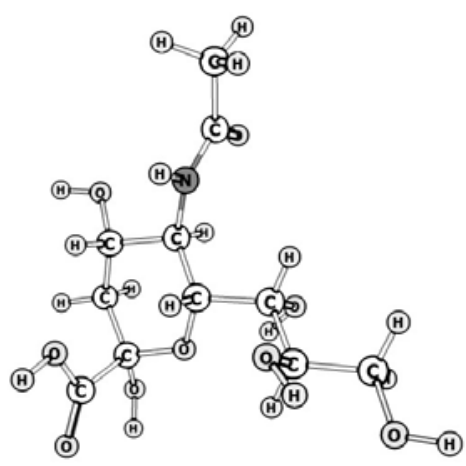

$b$

Fig. 2. Models: a - silica cluster, b - molecular form of N-acetylneuraminic acid

To determine the effect of water on the adsorption of NANA on the surface of silica with the participation of carbohydrate molecules, clusters of water molecules of different sizes (Fig. 3, a, b) and the products of their interaction with each other (Fig. 3, c, d) were used.

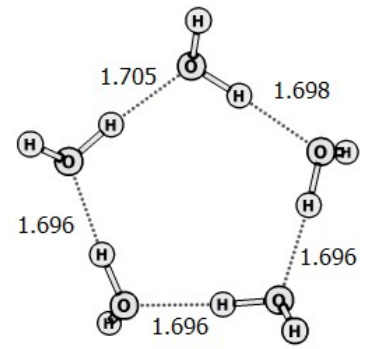

$a$

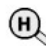

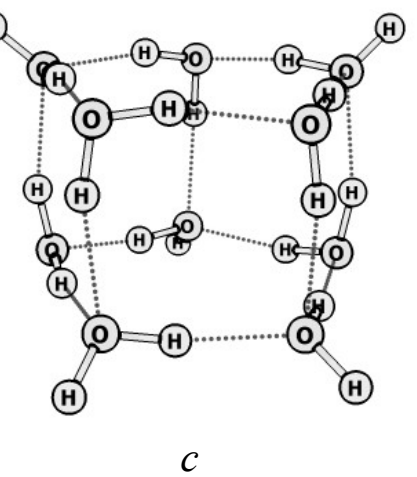

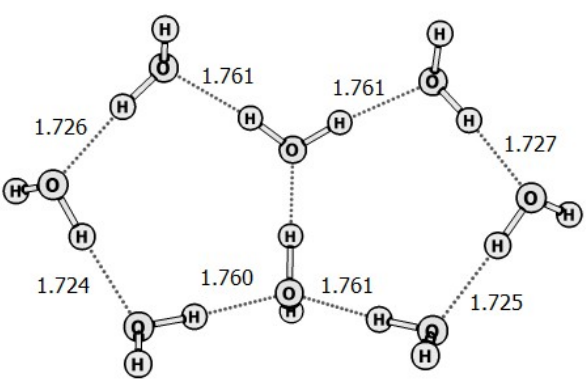

$b$

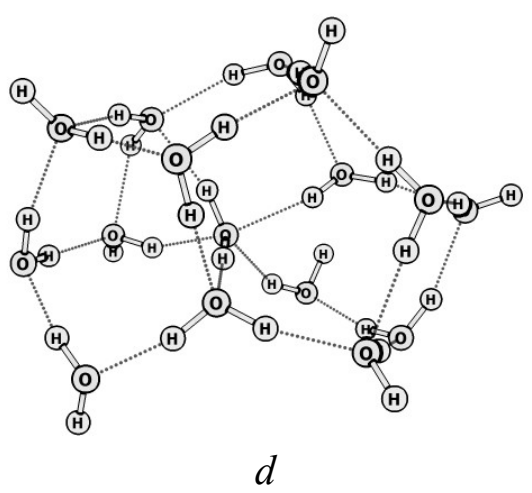

Fig. 3. Equilibrium spatial structure of intermolecular complexes: a - cluster of 5 water molecules, b

- cluster of 8 water molecules, c - cluster of 10 water molecules, b - cluster of 16 water molecules

Adsorption of $\mathrm{N}$-acetylneuraminic acid, as well as with individual carbohydrates glucose and sucrose, on the hydrated surface of silica in aqueous solution was considered as a process of replacement of water molecules on the surface of silica by adsorbate molecules (Fig. 4). 

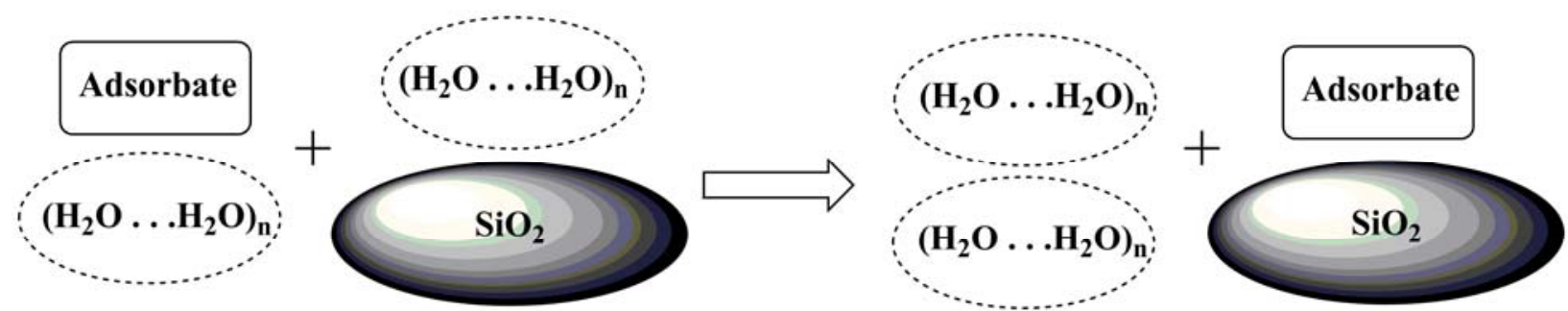

Fig. 4. Scheme of modeling of adsorption of hydrated adsorbate molecule on hydrated surface of silica

Adsorption energy $\left(\Delta \mathrm{E}_{a d s}\right)$ was calculated on the following formula:

$$
\begin{gathered}
\Delta \mathrm{E}_{a d s}=\left(\left(E_{\text {tot }}\left(2 \mathrm{n} \mathrm{H}_{2} \mathrm{O}\right)+E_{\text {tot }}\left(\mathrm{SiO}_{2} \cdots \text { Adsorbate }\right)\right)-\right. \\
-\left(\left(E_{\text {tot }} \text { (Adsorbate } \cdots \mathrm{n} \mathrm{H}_{2} \mathrm{O}\right)+E_{\text {tot }}\left(\mathrm{SiO}_{2} \cdots \mathrm{n} \mathrm{H}_{2} \mathrm{O}\right)\right)
\end{gathered}
$$

$E_{\text {tot }}\left(2 \mathrm{n} \mathrm{H}_{2} \mathrm{O}\right)$ - the total energy of the cluster, consisting of $2 \mathrm{n}$ water molecules, $E_{\text {tot }}\left(\mathrm{SiO}_{2} \cdots\right.$ Adsorbate $)$ - total energy of the adsorption complex, the surface of silica is a molecule of detachment, $E_{\text {tot }}$ (Adsorbate $\cdots \mathrm{n}_{2} \mathrm{O}$ ) - intermolecular complex of the adsorbate molecule with a water cluster, $E_{\text {tot }}\left(\mathrm{SiO}_{2} \cdots \mathrm{n} \mathrm{H}_{2} \mathrm{O}\right)$ - total energy of the hydrated surface of silica.

To assess the influence of water molecules on the adsorption process in aqueous solution, the hydration energy $\left(\Delta E_{h y d r}\right)$ is calculated as the energy of intermolecular interaction between the water cluster and the hydrated molecule, or the intermolecular complex (M) according to formula (2):

$$
\Delta E_{\text {hydr }}=E_{t o t}\left(\mathrm{M} \cdots \mathrm{n} \mathrm{H}_{2} \mathrm{O}\right)-\left(\left(E_{t o t}\left(\mathrm{n} \mathrm{H}_{2} \mathrm{O}\right)+\left(E_{t o t}(\mathrm{M})\right.\right.\right.
$$

$E_{\text {tot }}\left(\mathrm{M} \cdots \mathrm{n} \mathrm{H}_{2} \mathrm{O}\right)$ - total energy of the hydrated molecule. or intermolecular complex, $E_{\text {tot }}\left(\mathrm{n}_{2} \mathrm{O}\right)-$ the total energy of the cluster, consisting of n (5 or 8) water molecules, $E_{t o t}(\mathrm{M})$ - the total energy of the investigated molecule or intermolecular complex (M).

The adsorption of the N-acetylneuraminic acid molecule on the surface of silica with the participation of carbohydrates can be considered on the basis of two possible interaction schemes. According to the first scheme (Fig. 5): the interaction of the NANA molecule occurs with the silicacarbohydrate complex, according to the second scheme (Fig. 6), there is an interaction of the silica cluster with the NANA-carbohydrate complex where silica binds to the complex through the monosaccharide molecule [15].

Fig. 5 shows the influence of solvent molecules on the interaction according to the first scheme. According to this scheme, when the water cluster interacts with the hydrated NANA molecule, it is connected by hydrogen bonds with a similar water cluster. . And the NANA molecule binds to that carbohydrate molecule.

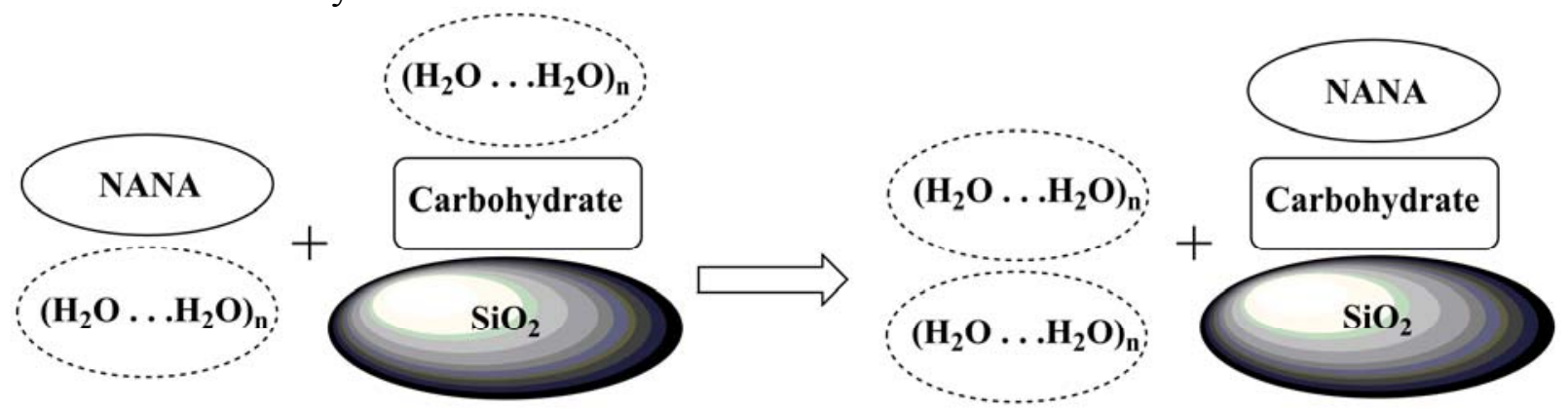

Fig. 5. Scheme 1 of the interaction of the adsorbate molecule with the surface of silica in aqueous solution 
Therefore, the energy of intermolecular interaction according to scheme $1\left(\Delta \mathrm{E}_{\text {scheme1 }}\right)$ was calculated on a formula:

$$
\begin{aligned}
\Delta E_{\text {schemel }} & =\left(E_{\text {tot }}\left(2 \mathrm{n} \mathrm{H}_{2} \mathrm{O}\right)+E_{\text {tot }}\left(\mathrm{SiO}_{2}-\text { Carbohydr. }-N A N A\right)\right)- \\
& -\left(\left(E\left(N A N A \cdots \mathrm{n} \mathrm{H}_{2} \mathrm{O}\right)+E_{\text {tot }}\left(\mathrm{SiO}_{2}-\text { Carbohydr. }-\mathrm{n} \mathrm{H}_{2} \mathrm{O}\right)\right),\right.
\end{aligned}
$$

where $E_{\text {tot }}\left(\mathrm{SiO}_{2}-\right.$ Carbohydr.-NANA) - total energy of the adsorption complex silica surface carbohydrate molecule - N-acetylneuraminic acid, $E_{t o t}\left(N A N A \cdots \mathrm{n} \mathrm{H}_{2} \mathrm{O}\right)$ - total energy of the intermolecular complex consisting of a molecule of $\mathrm{N}$-acetylneuraminic acid and a cluster of water, $E_{\text {tot }}\left(\mathrm{SiO}_{2}-\right.$ Carbohydr. $\left.-\mathrm{n} \mathrm{H}_{2} \mathrm{O}\right)$ - the total energy of the intermolecular complex of the surface of silica and hydrated carbohydrate.

The interaction of the silica surface with the intermolecular complex NANA - carbohydrate, was calculated according to scheme 2, which is presented in Fig. 6 by formula (4).

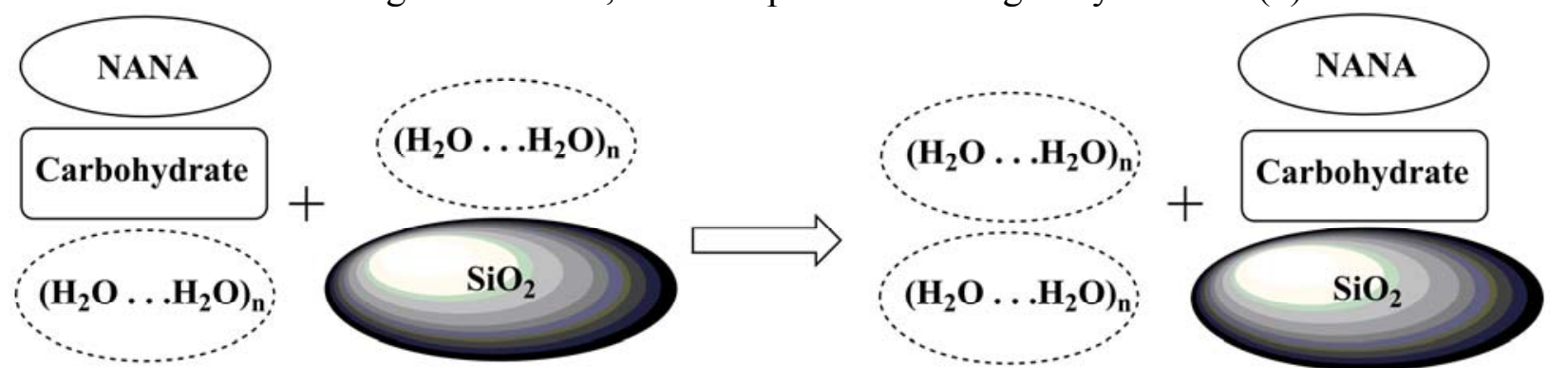

Fig. 6. Scheme 2 of the interaction of the adsorbate molecule with the surface of silica in aqueous solution

$$
\begin{aligned}
\Delta E_{\text {scheme } 2} & =\left(E_{\text {tot }}\left(2 \mathrm{n} \mathrm{H}_{2} \mathrm{O}\right)+E_{\text {tot }}\left(\mathrm{SiO}_{2}-\text { Carbohydr. }-N A N A\right)\right)- \\
& -\left(\left(E\left(\text { Carbohydr. }-N A N A-\mathrm{n} \mathrm{H}_{2} \mathrm{O}\right)+E_{\text {tot }}\left(\mathrm{SiO}_{2}-\mathrm{n} \mathrm{H}_{2} \mathrm{O}\right)\right),\right.
\end{aligned}
$$

where $E_{\text {tot }}\left(\right.$ Carbohydr.-NANA-n $\left.\mathrm{H}_{2} \mathrm{O}\right)$ - total energy of the intermolecular complex consisting of a molecule of $\mathrm{N}$-acetylneuraminic acid and a hydrated molecule of carbohydrate.

All quantum chemical calculations were performed using the program GAMESS (US) [17] by the method of density functional theory (DFT) with functional B3LYP $[18,19]$ and basic set 6$31 \mathrm{G}(\mathrm{d}, \mathrm{p})$ taking into account the Grimm variance correction D3 [20, 21 ] within the polarization continuum of the PCM $[22,23]$.

\section{Results and discussions}

First, it is necessary to elucidate the effect of hydration on the adsorption energy of individual NANA molecules, glucose and sucrose on the surface of silica.

With this purpose a reaction schematically shown in Fig. 4 was considered. Based on the fact that in aqueous solution solvent molecules can interact with both the adsorbate molecule and the surface of the adsorbent and taking into account this interaction is necessary when calculating the adsorption energy of a substance in a particular solvent not only in a continuous approximation [23] but also explicitly. in the supermolecular approximation [24]. In our case, the solvent is water and its molecules form hydrogen bonds with both the silica surface and the adsorbate molecule, so adsorption in aqueous solution is considered as a process of exchange of the adsorbate molecule cluster of water molecules commensurate with the studied adsorbate molecule (NANA, glucose and sucrose). The energy effect of the process was calculated on formula (1) where $\Delta \mathrm{E}_{a d s}$ is defined as the difference between the sums of total energies of the reaction products and starting materials. 
The water cluster selected for this study consisted of five water molecules combined into a five-membered ring (Fig. 10, a), the so-called homodrome cluster [25]. Its size is similar to the studied molecules and according to the literature $[26,27]$, it is the most thermodynamically stable cluster of the smallest possible and experimentally recorded in both solid and liquid and gaseous phases.

This cluster forms hydrogen bonds with a cluster of silica, NANA molecules, glucose and sucrose (Fig. 6) without destroying the original similar compounds and without breaking the fivemembered ring, there is only a slight deformation.

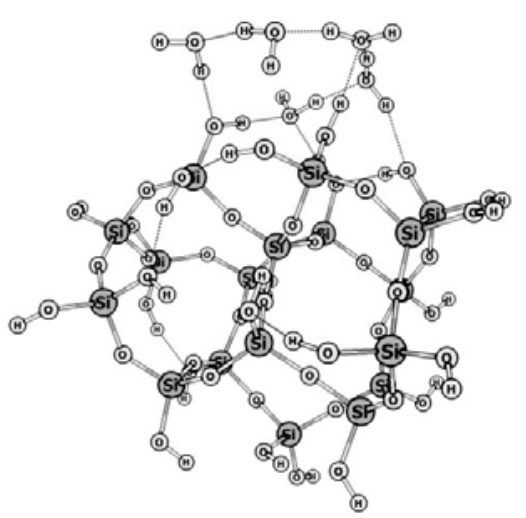

$a$

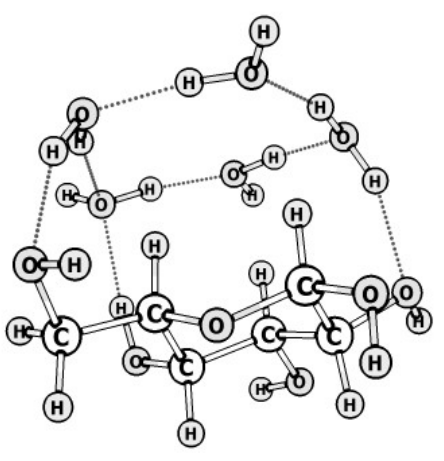

c

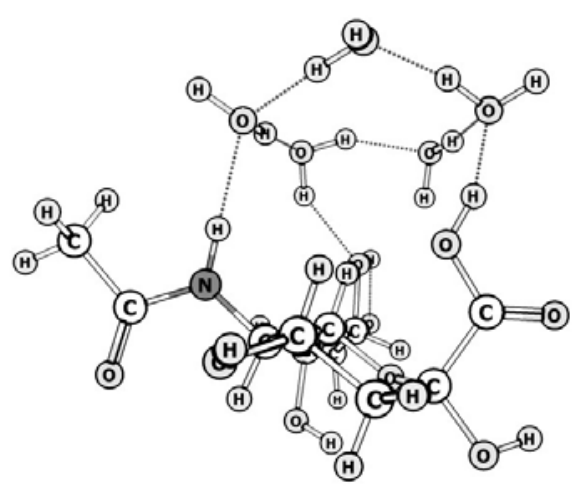

$b$

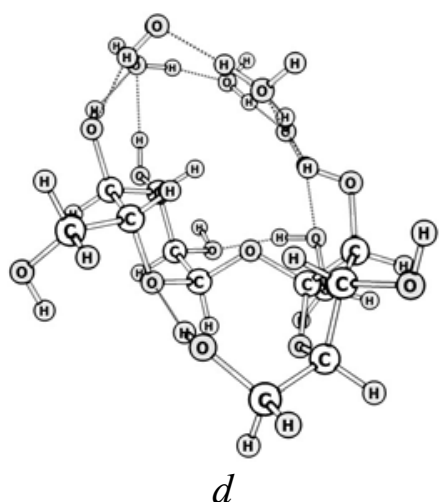

Fig. 8. Hydrated intermolecular complexes consisting of 5 molecules of water and silica (a), N acetylneuraminic acid (b), glucose (c) and sucrose (d)

To determine how the size of the selected water cluster affects the adsorption energy, a larger water cluster was used (Fig. 3, b), which is similar to the discussed above and is an eightmembered complex formed of two condensed five-membered ones. This cluster of water is commensurate with the NANA molecule (Fig. 9, b). In addition, as can be seen from Fig. 8, c and 9, $\mathrm{d}$, a five-membered water cluster is proportional to the glucose molecule, and an eight-membered complex is proportional to the sucrose molecule. 


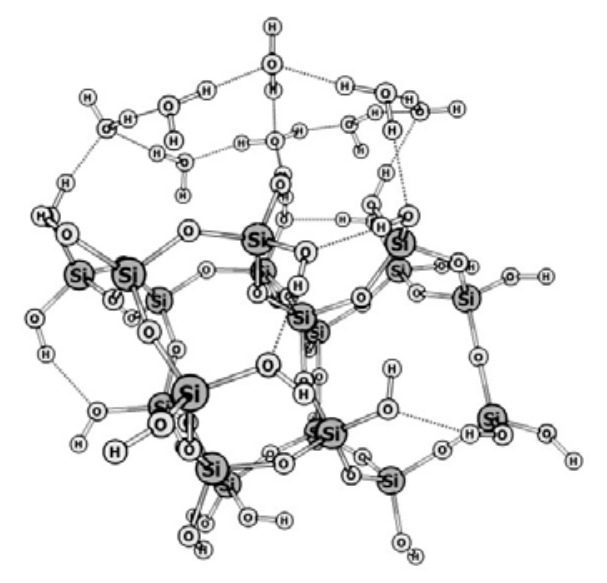

$a$

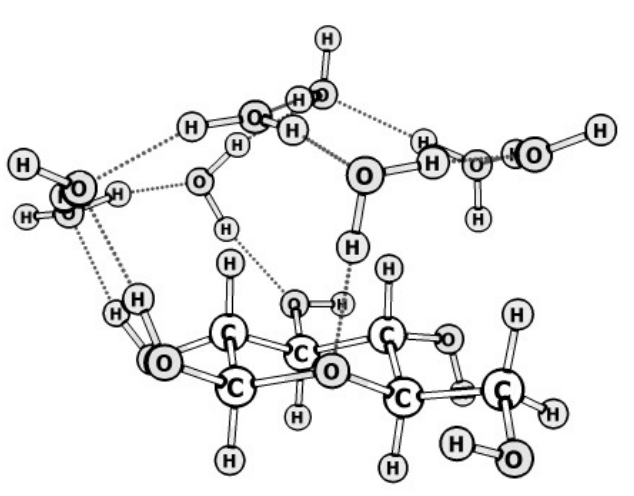

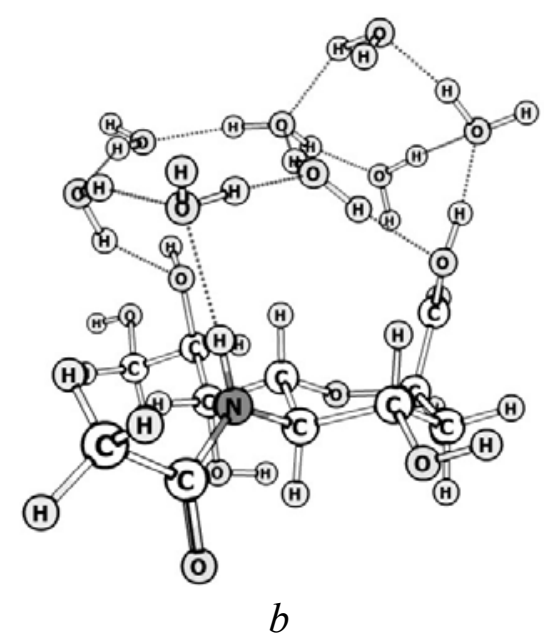

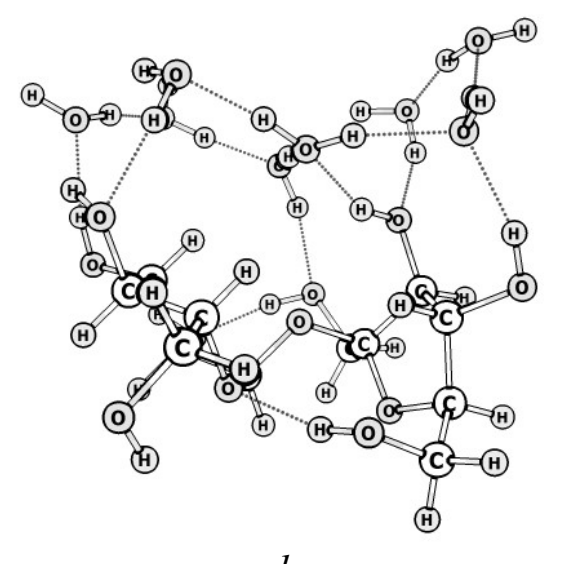

$d$

Fig. 9. Hydrated intermolecular complexes consisting of 8 molecules of water and silica (a), N acetylneuraminic acid (b), glucose (c) and sucrose (d)

Our previous works $[15,16]$ show that the results of adsorption are intermolecular complexes formed due to the occurrence of intermolecular hydrogen bonds between silanol groups of silica surface and hydroxyl groups of carbohydrates and NANA (Fig. 10). Other reaction products are $2 \mathrm{nH} 2 \mathrm{O}$ clusters formed due to the interaction of smaller clusters of two five-membered (Fig. 3, c) and two eight-membered cycles (Fig. 3, d).

The calculations according to equation (1) of adsorption energy for NANA and carbohydrates are presented in table. 1. Here we can see that the adsorption of the NANA molecule is unlikely on the surface of silica, because the calculated values are close to $0 \mathrm{~kJ} / \mathrm{mol}$, in particular $-1.3 \mathrm{~kJ} / \mathrm{mol}$, for the reaction with five molecules of water and $+0.9 \mathrm{~kJ} / \mathrm{mol}$ - of eight water molecules confirmed by experimental data [5].

The calculated values of $\Delta \mathrm{E}_{a d s}$ of glucose on the surface of silica in aqueous solution have positive values $(+9.8$ and $+2.7 \mathrm{~kJ} / \mathrm{mol})$ and are proof that the process is unfavorable in terms of thermodynamics, regardless of the size of the water cluster, which is displaced from silica surface in the process of adsorption, which is also consistent with experimental results [8]. 


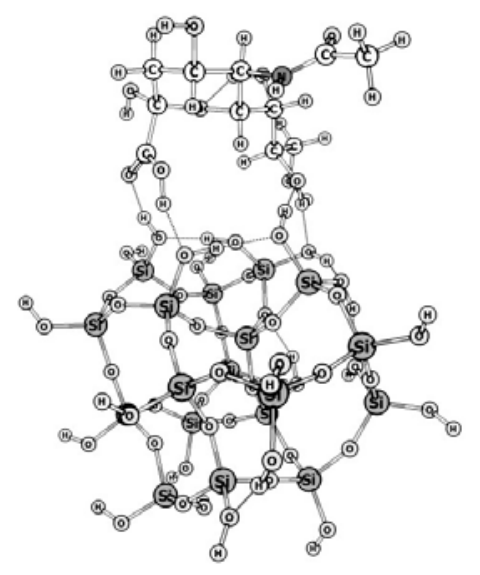

$a$

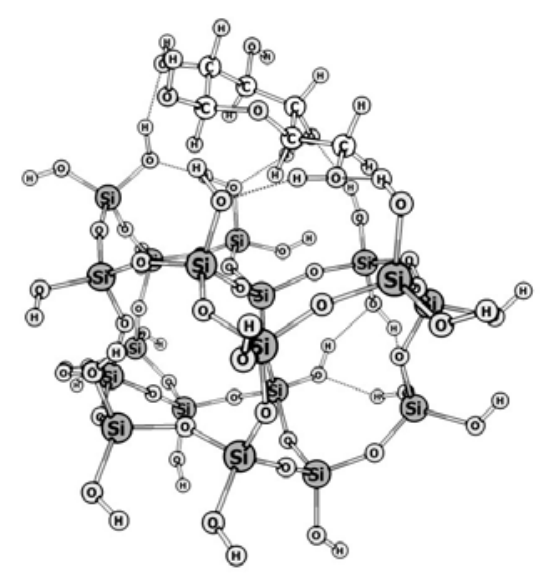

$b$

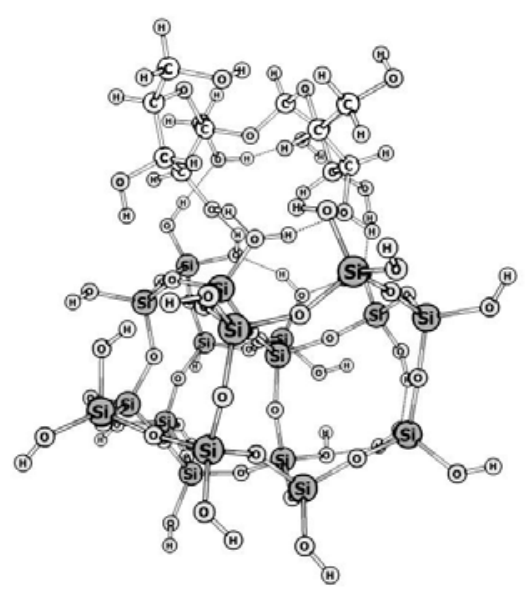

$c$

Fig. 10. Adsorption complexes of silica with $\mathrm{N}$ - acetylneuraminic acid (a) and saccharides: glucose (b), sucrose (c)

It is interesting that adsorption energy for the sucrose molecule, despite its derivative of the glucose molecule, has a negative value, despite the size of the hydrating water cluster ( -33.0 and $24.5 \mathrm{~kJ} / \mathrm{mol}$ ), which indicates the thermodynamic probability of adsorption of this substance in aqueous solution on the surface of silica.

Table 1. Adsorption energy (adsEads) and hydration energy ( $\Delta$ Ehydr) in aqueous solution of test substances (in $\mathrm{kJ} / \mathrm{mol}$ )

\begin{tabular}{c|c|c|c|c}
\hline $\begin{array}{c}\text { Hydrating } \\
\text { water clusters }\end{array}$ & $\mathrm{Si}_{18} \mathrm{O}_{48} \mathrm{H}_{24}$ & NANA & Glucose & Sucrose \\
\cline { 2 - 5 } & \multicolumn{5}{|c|}{ Adsorption energy } \\
\hline $5 \mathrm{H}_{2} \mathrm{O}$ & - & $-1,3$ & $+9,8$ & $-33,0$ \\
\hline $8 \mathrm{H}_{2} \mathrm{O}$ & - & $+0,9$ & $+2,7$ & $-24,5$ \\
\hline & \multicolumn{5}{|c}{ Hydration energy } \\
\hline $5 \mathrm{H}_{2} \mathrm{O}$ & $-193,6$ & $-147,3$ & $-153,4$ & $-161,3$ \\
\hline $8 \mathrm{H}_{2} \mathrm{O}$ & $-217,0$ & $-192,4$ & $-189,2$ & $-212,7$ \\
\hline
\end{tabular}

The hydration energies $\left(\Delta E_{h y d r}\right)$ calculated on the formula (2) for the considered compounds (Table 1) correlate with the sizes of water clusters that hydrate and have larger values, as expected for clusters with more water molecules. The highest values of $\Delta E_{h y d r}$ are characteristic for the silica cluster regardless of the size of the water cluster. This is because there are silanol groups and siloxane bridges (Fig. 8, a and Fig. 9, a) on the surface of the silica. They are able to form hydrogen bonds with the water cluster. All other molecules, both NANA and carbohydrates, have quite large values of $\Delta E_{h y d r}$ (greater than $140 \mathrm{~kJ} / \mathrm{mol}$ ) because these molecules also contain functional hydroxyl groups and oxygen bridges through which they are hydrated. Therefore, the break of hydrogen bonds between the water clusters and the adsorbate molecules, as well as between the water clusters and the silica surface is necessary for adsorption process on $\mathrm{SiO}_{2}$ surface. Hydrogen bonds are then formed between the adsorbent and the adsorbate.

The next step in the study was to determine the effect of glucose and sucrose molecules on NANA adsorption. This effect can be described by two alternative schemes, according to "scheme 1" (Fig. 5) the hydrated molecule NANA (Fig. 8, b and 9, b) interacts with the hydrated molecule of 
the corresponding carbohydrate already adsorbed on the surface of silica. Equilibrium geometry of these complexes with glucose (Fig. 11) and sucrose (Fig. 12) with water clusters of different sizes.
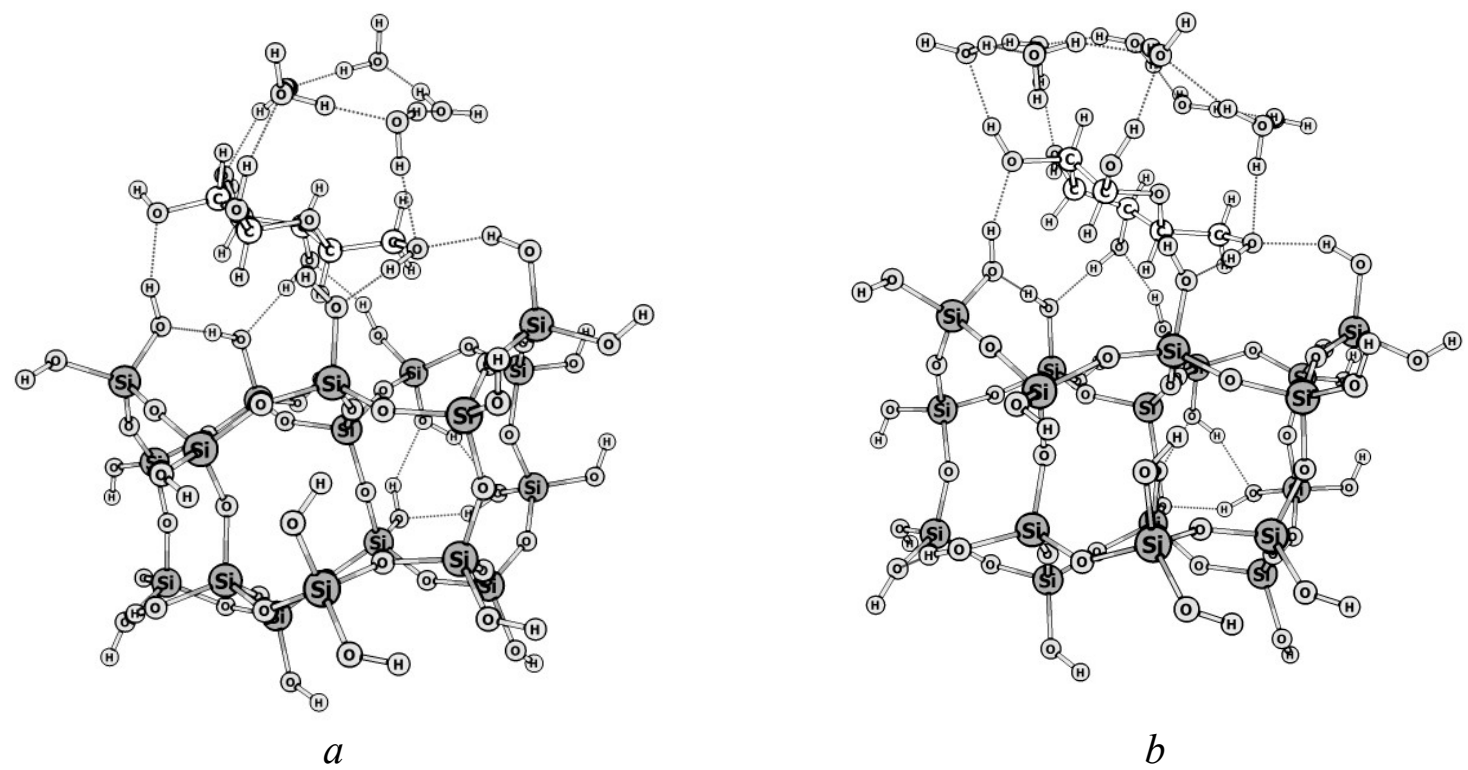

Fig. 11. Hydrated intermolecular complexes consisting of silica, glucose and 5 molecules of water (a), a similar complex with an eight-membered cluster of water (b)

As you may see in these figures, water clusters form hydrogen bonds with carbohydrate molecules of intermolecular complexes without destroying the original similar compounds and without breaking the five-membered (Fig. 3, a) and eight-membered (Fig. 3, b) ring. A slight deformation occurs only.

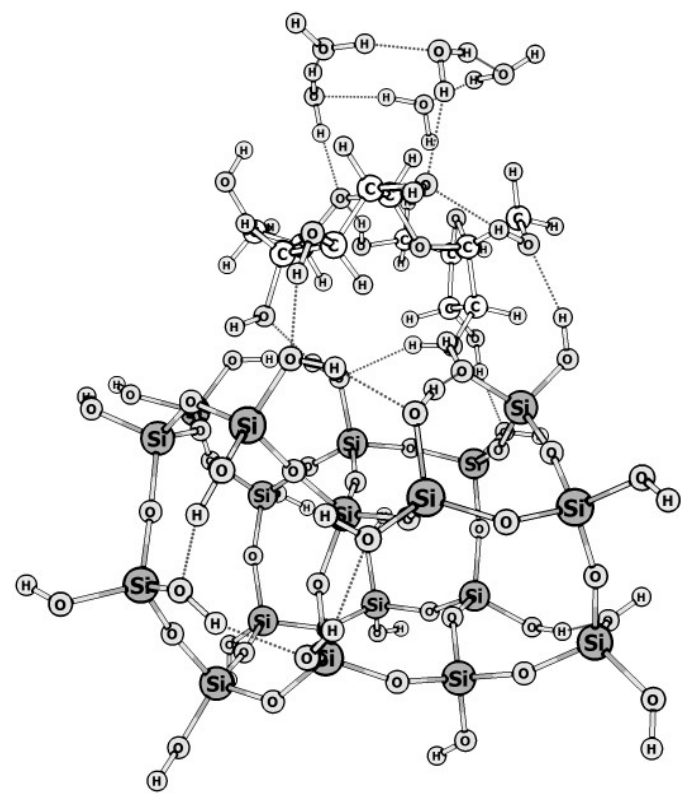

$a$

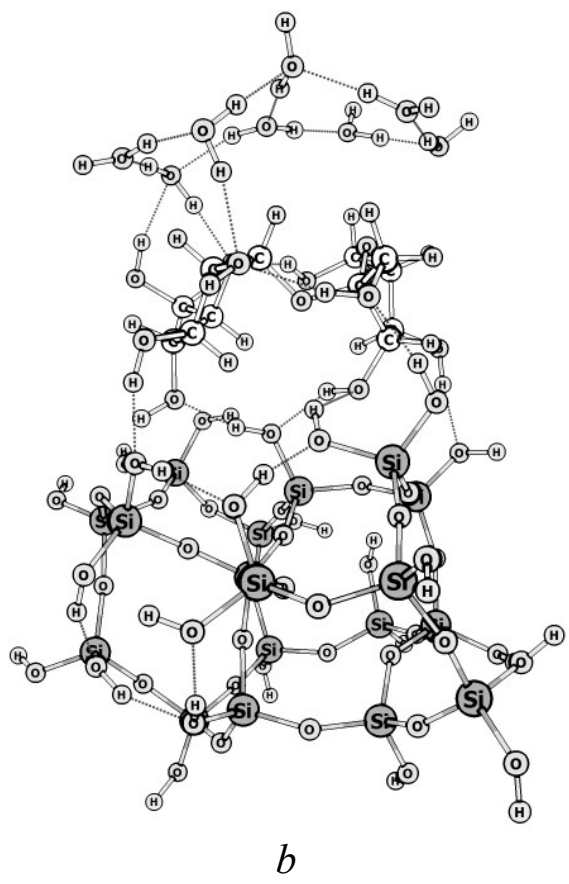

$b$

Fig. 12. Equilibrium geometry of three-component intermolecular complexes consisting of silica, sucrose and $5 \mathrm{H}_{2} \mathrm{O}$ (a), a similar complex with the composition of $\mathrm{SiO}_{2}$ - sucrose $-8 \mathrm{H}_{2} \mathrm{O}$ (b) 
As a result of the interaction, three-component intermolecular complexes $\mathrm{SiO}_{2}-$ Glucose NANA (Fig. 13, a) and $\mathrm{SiO}_{2}-$ Sucrose - NANA (Fig. 13, b) are formed. We have considered and described earlier $[15,16]$. Other reaction products are water clusters (Figs. 3, c, and d) formed by the interaction of smaller water clusters. The energy effects $\left(\Delta E_{\text {schemel }}\right)$ for these systems calculated on the formula (3), show (Table 2) that regardless of the water cluster size, the interaction energy between NANA and glucose, previously adsorbed on the surface of silica, is much greater than the absolute value $\left(-71.8 \mathrm{~kJ} / \mathrm{mol}\right.$ for $5 \mathrm{H}_{2} \mathrm{O}$ and $-20.1 \mathrm{~kJ} /$ mol for $8 \mathrm{H}_{2} \mathrm{O}$ ), compared with the adsorption energy of the NANA molecule on the surface of silica (Table 1), where this value was only $-1.3 \mathrm{~kJ} / \mathrm{mol}$ for $5 \mathrm{H}_{2} \mathrm{O}$ and $+0.9 \mathrm{~kJ} / \mathrm{mol}$ for $8 \mathrm{H}_{2} \mathrm{O}$.
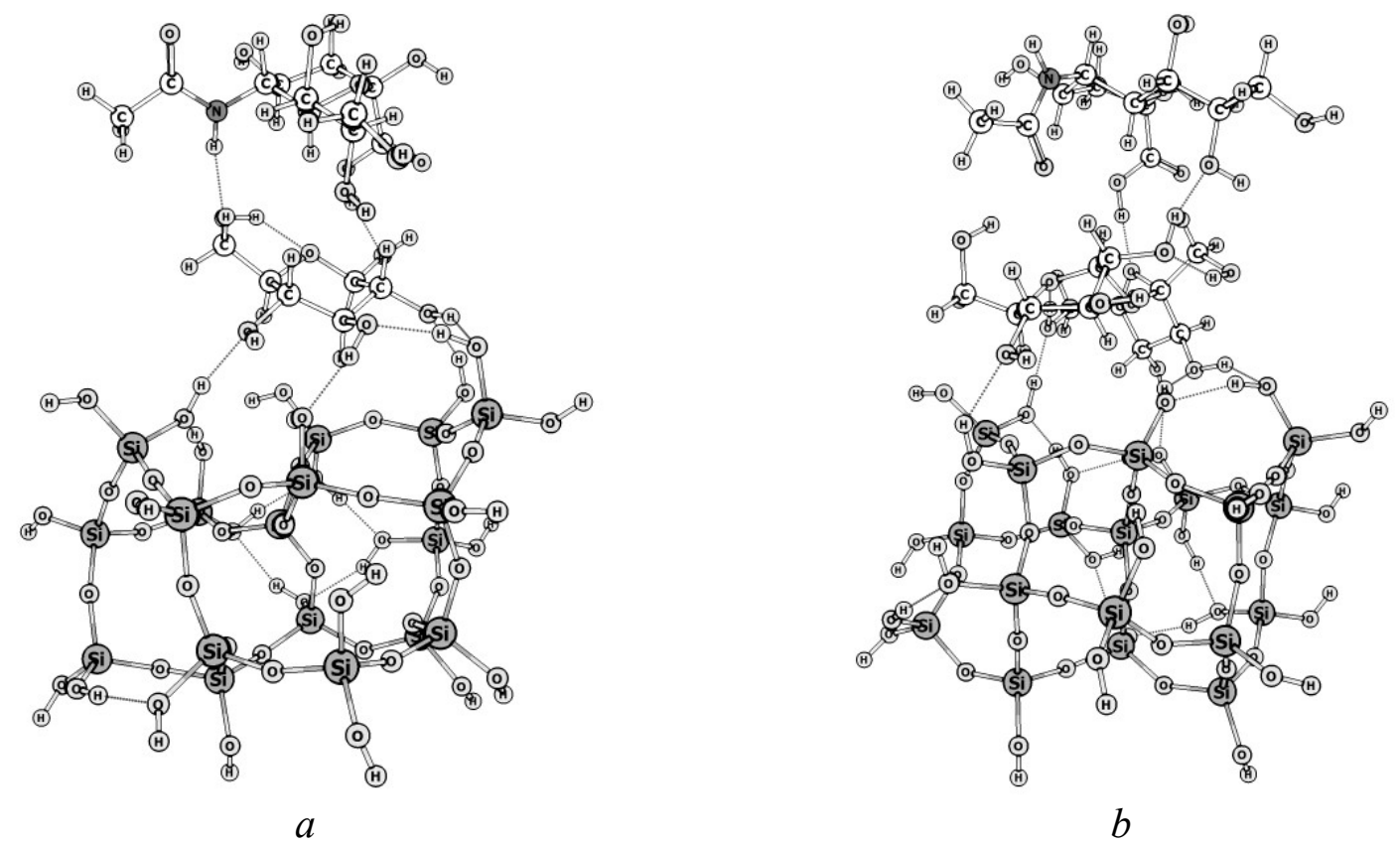

Fig. 13. Equilibrium geometry of three-component intermolecular complexes consisting of silica, glucose and $\mathrm{N}$ - acetylneuraminic acid (a), a similar complex with the composition of $\mathrm{SiO}_{2}$ - Sucrose-NANA (b)

According to "scheme 2", shown in Fig. 6, the hydrated surface of silica interacts with the intermolecular hydrated on the carbohydrate side of the NANA-carbohydrate complex, while the interaction with the $\mathrm{SiO}_{2}$ surface occurs on the carbohydrate side.

The optimized intermolecular NANA-glucose complexes with five-membered water clusters are presented in Fig. 14, $a$, as well as a similar complex of sucrose molecules with the same size of the water cluster (Fig. 14, b,). A rather complex system of hydrogen bonds is formed by intermolecular NANA-carbohydrate complexes with eight-membered water clusters (Fig. 15).

As a result of the reaction according to this scheme (Fig. 6), as in the previous one (Fig. 5), three-component intermolecular complexes $\mathrm{SiO}_{2}-$ Glucose - NANA (Fig. 13, a) and $\mathrm{SiO}_{2}-$ Sucrose - NANA are formed (Fig. 13, b). , as well as larger water clusters (Fig. 3, c and d).

Analysis of the calculation results made on formula (4) shows (Table 2) that as in the previous case the values of the interaction energy $\Delta \mathrm{E}_{\text {scheme } 2}$ hydrated intermolecular NANA-glucose with hydrated silica surface, regardless of the size of the water cluster are greater than absolute data on NANA adsorption energy on the surface of silica in aqueous solution (see table. 1) and is -45.1 
$\mathrm{kJ} / \mathrm{mol}$ in the case of a cluster of $5 \mathrm{H}_{2} \mathrm{O}$, and $-21.8 \mathrm{~kJ} / \mathrm{mol}$ in the case of hydration by an eightmembered cluster of water.
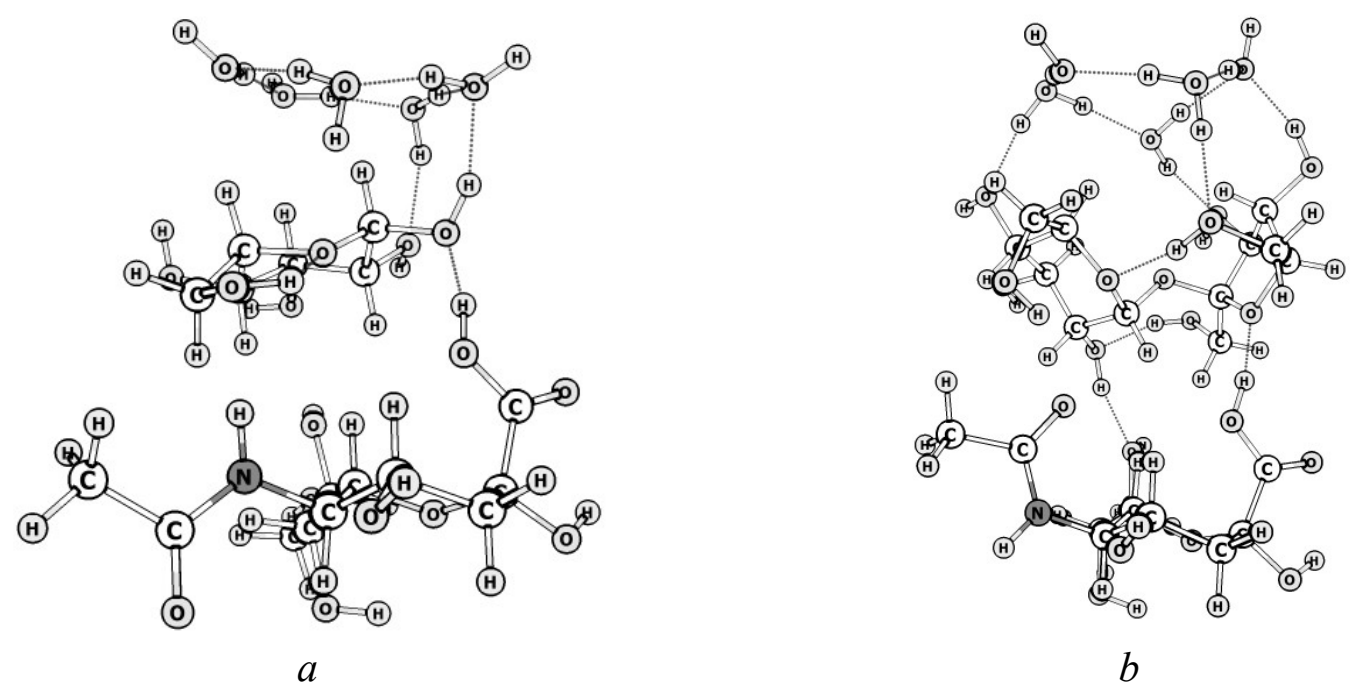

Fig. 14. Hydrated by five molecules of water intermolecular complexes, composition NANAGlucose- $5 \mathrm{H}_{2} \mathrm{O}(\mathrm{a})$, and complex NANA-Sucrose $-5 \mathrm{H}_{2} \mathrm{O}(\mathrm{b})$

In the case of sucrose, the value of $\Delta E_{\text {schemez }}$ in hydration with a five-membered cluster of water is almost the same as in the case of glucose and is $-41.9 \mathrm{~kJ} / \mathrm{mol}$, and $E_{\text {schemez }}$. When hydrated with an eight-membered water cluster, this value is much larger in absolute value and is $-87.7 \mathrm{~kJ} /$ mol.

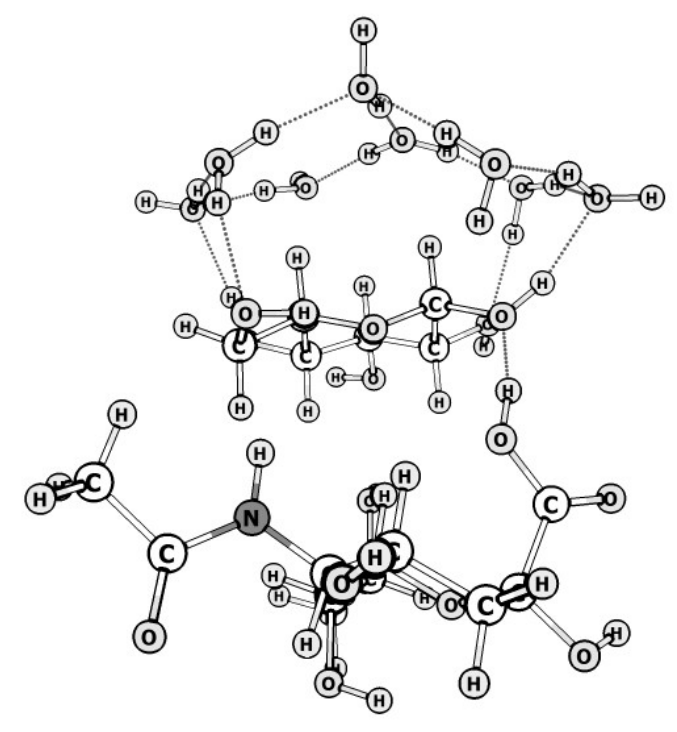

$a$

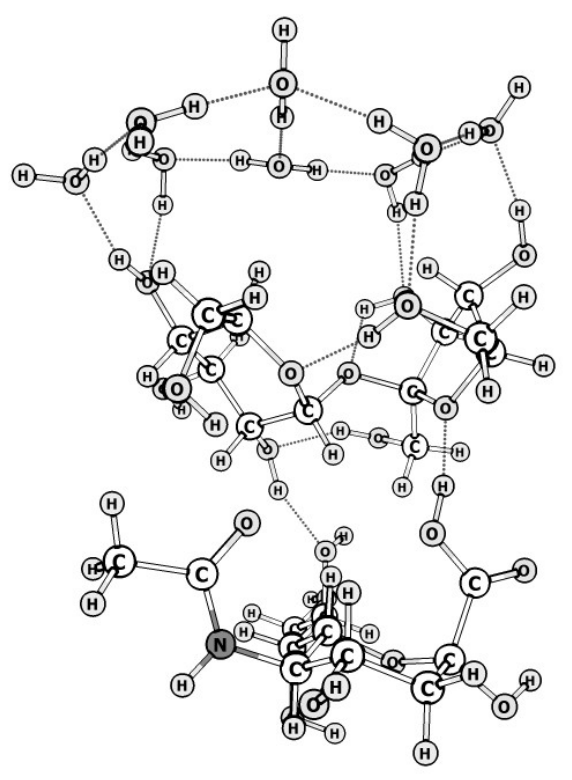

$b$

Fig. 15. Hydrated intermolecular complexes consisting of $\mathrm{N}$ - acetylneuraminic acid, sucrose and 5 molecules of water (a), a similar complex with an eight-membered water cluster

When comparing the values of the energy of intermolecular interaction, $\mathrm{E}_{\text {scheme2 }}$ and $\Delta \mathrm{E}_{\text {scheme2, }}$, it is seen that they do not differ significantly. However, it should be noted that for 
complexes with five water molecules, regardless of the nature of the carbohydrate, about $25 \mathrm{~kJ} /$ mol, scheme 1 is thermodynamically more likely than scheme 2 .

The common thing for both schemes (1 and 2) is that in the case of sucrose from 8 water molecules, the values of the energy of intermolecular interactions have a maximum value of $-86.2 \mathrm{~kJ}$ / mol, for scheme 1 and $-87.7 \mathrm{~kJ} / \mathrm{mol}$ for scheme 2 , respectively. It means that the interaction of the NANA molecule with the surface of silica is thermodynamically more likely to form an adsorption complex in the presence of a sucrose molecule.

Table 2. Energy of intermolecular interaction according to scheme $1\left(\Delta \mathrm{E}_{\text {schemel }}\right)$ and scheme 2 $\left(\Delta \mathrm{E}_{\text {scheme2 }}\right)$ in aqueous solution for three-component systems $\mathrm{SiO}_{2}-$ Carbohydr. - NANA (in $\mathrm{kJ} / \mathrm{mol}$ )

\begin{tabular}{|c|c|c|c|c|}
\hline \multirow{2}{*}{$\begin{array}{c}\text { Hydrating } \\
\text { water clusters }\end{array}$} & \multicolumn{2}{|c|}{ Scheme 1 } & \multicolumn{2}{c|}{ Scheme 2 } \\
\cline { 2 - 5 } & Glucose & Sucrose & Glucose & Sucrose \\
\hline $5 \mathrm{H}_{2} \mathrm{O}$ & $-71,8$ & $-65,1$ & $-45,1$ & $-41,9$ \\
\hline $8 \mathrm{H}_{2} \mathrm{O}$ & $-20,5$ & $-86,2$ & $-21,8$ & $-87,7$ \\
\hline
\end{tabular}

Calculations of $\Delta E_{\text {hydr }}$ values in the case of a five-membered cluster of water for glucose (as mentioned above the glucose molecule is proportional to the size of a five-membered cluster of water, so it is correct to compare in the case of $5 \mathrm{H}_{2} \mathrm{O}$ ) adsorbed on the surface of silica, a) and in complex with the NANA molecule (Fig. 14, a) are slightly smaller (-120.9 and $-126.5 \mathrm{~kJ} / \mathrm{mol})$ for similar values $(-153.4 \mathrm{~kJ} / \mathrm{mol}$, see Table 1$)$ for the glucose molecule, for the complex shown in Fig.8, b. It may cause the better adsorption of the NANA molecule in complex with the glucose molecule on the surface of silica, although these substances alone are not adsorbed on silica in aqueous solution (Table 1).

In the case of sucrose, which is commensurate with the cluster $8 \mathrm{H}_{2} \mathrm{O}, \Delta E_{\text {hydr }}$ for the NANA Sucrose complex (Fig. 15, b) is also smaller (-182.9 kJ / mol) compared to the same value for a single molecule of sucrose $\left(-212,7 \mathrm{~kJ} / \mathrm{mol}\right.$, see Table 1). A similar situation is typical for the $\mathrm{SiO}_{2}$ Sucrose complex (Fig. 12, b) where the binding energy of the water cluster to the sucrose molecule is lower and is $-189.8 \mathrm{~kJ} / \mathrm{mol}$. In addition, this value is also lower in absolute value compared to $\Delta \mathrm{E}_{\text {hydr }}$ for the silica surface $(-217.0 \mathrm{~kJ} / \mathrm{mol}$, see table. 1$)$. In view of the above, it can be argued that in the aqueous solution the presence of sucrose on the silica surface weakens the hydration energy (i.e. it is easier to replace the $\mathrm{N}$-acetylneuraminic acid molecule with a cluster of water from the surface of the modified adsorbent) which in turn promotes NANA adsorption on the silica surface.

\section{Conclusions}

The results of the analysis of quantum chemical calculations show that adsorption on the surface of silica, with hydration taken into account, is thermodynamically probable for the sucrose molecule, regardless of the hydrating water cluster size $(-33.0$ and $-24.5 \mathrm{~kJ} / \mathrm{mol})$. The adsorption of the glucose molecule has a positive value $(+9.8$ and $+2.7 \mathrm{~kJ} / \mathrm{mol})$ and is a process unfavorable from the point of view of thermodynamics regardless of the size of the water cluster, and the $\mathrm{N}$ acetylneuraminic acid molecule has small calculated adsorption values, in particular - $1.3 \mathrm{~kJ} / \mathrm{mol}$, for the reaction with five water molecules and $+0.9 \mathrm{~kJ} / \mathrm{mol}$ - with eight water molecules.

The values of hydration energy $\left(\Delta \mathrm{E}_{\mathrm{hydr}}\right)$ for the considered compounds correlate with the sizes of hydrating water clusters, and larger values, as expected for clusters with more water 
molecules. The highest values of $\Delta \mathrm{E}_{\text {hydr }}$ are for the silica cluster, regardless of the size of the water cluster, because there are silanol groups and siloxane bridges on the surface of the silica, which are able to form hydrogen bonds with the water cluster. All other molecules, both NANA and carbohydrates, have quite large values of $\Delta \mathrm{E}_{\text {hydr }}$ (greater than $140 \mathrm{~kJ} / \mathrm{mol}$ ), because these molecules also contain functional hydroxyl groups and oxygen bridges, through which they are hydrated.

For complexes with five molecules of water, regardless of the nature of the carbohydrate, about $25 \mathrm{~kJ} / \mathrm{mol}$ scheme 1 is thermodynamically more likely than scheme 2 .

It was found that the presence of sucrose on the silica surface in the aqueous solution weakens the hydration energy (i.e. it is easier to replace the cluster of water with the Nacetylneuraminic acid molecule from the surface of the modified adsorbent), which in turn promotes NANA adsorption on the silica surface.

This shows that there is a mutual influence of substances in the mixture of NANA with carbohydrates on the interaction with silica in comparison with the interaction of substances with silica alone.

Therefore, as studies have shown, the adsorption of $\mathrm{N}$-acetylneuraminic acid is possible if the surface of the silica is pre-modified with carbohydrates, which is confirmed by experimental data.

\section{Gratitude}

The authors thank Olga Kozakova, a senior researcher and candidate of chemical sciences, for constructive criticism and useful advice in creating the idea of modeling the influence of water molecules on adsorption processes in aqueous solution.

\section{References}

1. Syrova G.O., Petyunina V.M., Makarov V.O., Lukyanova L.V. Fundamentals of bioorganic chemistry (textbook). Kharkiv: KhNMU. - 2018. (in Ukrainian)

2. Kochetkov N.K., Bochkov A.F., Dmitrievidr B.A. Chemistry of carbohydrates. M. Chemistry. 1967. (in Russian)

3. Reutov O.A., Kurtz A.L., Butin K.P. Organic chemistry. In 4 volumes. M. Binom. Knowledge Laboratory. - 2004. (in Russian)

4. $\quad$ Patey L.M., Orel I.L., Galagan N.P. Nanocomposites based on highly dispersed silica and sucrose and its effect on the surface of human erythrocytes. Bull. of Odessa Nat. Univ. Series "Chemistry" 2004. 9 (6): 75. (in Ukrainian)

5. Nedava V.E., Smirnova O.I., Zhuravel M.P., etc. On the use of highly dispersed silica in media for freezing sheep semen. Agricultural Biol.: Animal Biol. series. 1992. 4: 20. (in Ukrainian)

6. Galagan N.P., Sinelnik A.P., Bogomaz V.I. etc. Silica modified with carbohydrates promising drugs for cryopreservation of sheep sperm. In: IV All-Union Conf. "Biological activity of silicon, germanium and tin compounds". Thesis. Report. June.( Irkutsk, 1990. Russia) P. 67.(in Russian)

7. Polesia T.L PhG (medicine). Thesis. (Vinnytsia, 1992). (in Ukrainian)

8. $\quad$ Kulyk T. V. PhD (chem). Thesis. (Kyiv, 2000) (in Ukrainian)

9. Kulyk T.V., Palyanytsya B.B., Halahan N.P. Molecular self-organization in nano-sized particles - carbohydrates. Nanosystemy, nanomaterialy, nanotekhnolohiyi. K.: Academiperidology, 2003. 1 (2): 681 (in Ukrainian) 
10. G.Parfit, K. Rochester. Adsorbtion from solutions on solid surfaces: translation from English. (Publishing house Mir, Moscow, 1986).

11. Kiselyov A.V. Intermolecular interactions in adsorption and chromatography ( M .: Higher school, 1986).(in Russian)

12. Eltekova N.A., Eltekov Yu. A. Adsorption of mono- and disaccharides on the surface of aminated silica. Journal of Phys. Chem. 2006. 80(4): 695. (in Russian)

13. M. B. Smith March's Advanced Organic Chemistry: Reactions, Mechanisms, and Structure, 8th Edition Wiley 2019: 2144.

14. Brown G. M., Levy H. A. Further refinement of the structure of sucrose based on neutrondiffraction data. Acta Cryst.1973. 29: 790-797.

15. Ushakova L.M., Demianenko E.M., Terets M.I., Lobanov V.V., Kartel N.T. A study on the interaction of the $\mathrm{N}$-acetylneuraminic acid with monosaccharides adsorbted on ultrafine silica surface. Chemistry physics and surface technology. 2020. 11 ( 3): 420-428.

16. L.M. Ushakova, E.M. Demianenko, M.I. Terets, V.V. Lobanov, N.T. Kartel Analysis of the interaction between n-acetylneuraminic acid and disaccharides on silica surface. Chemistry, Physics and Technology of Surface. 2020. V. 11(4): 516-527.

17. Schmidt M.W., Baldridge K.K., Boatz J.A., Elbert S.T., Gordon M.S., Jensen J.H., Koseki S., Matsunaga N., Nguyen K.A., Su S.J., Windus T.L., Dupuis M., Montgomery J.A. General atomic and molecular electronic structure system. J. Comput. Chem. 1993. 14(11): 1347.

18. Becke A.D. Density functional thermochemistry. III. The role of exact exchange. J. Chem. Phys. 1993. 98(7): 5648.

19. Lee C., Yang W., Parr R. G. Development of the Colle-Salvetti correlation-energy formula into a functional of the electron density. Phys. Rev. B. 1988. 37(2): 785.

20. Grimme S. Density functional theory with London dispersion corrections. WIREs Comput. Mol. Sci. 2011. 1: 211.

21. Grimme S., Ehrlich S., Goerigk L. Effect of the Damping Function in Dispersion Corrected Density Functional Theory J. Comput Chem. 2011. 32: 1456.

22. Cossi M., Barone V., Cammi R., Tomasi J. Ab initio study of solvated molecules: a new implementation of the polarizable continuum model. Chem. Phys. Lett. 1996. 255(4-6): 327.

23. Tomasi J., Mennucci B., Cammi R. Quantum Mechanical Continuum Solvation Models. Chem. Rev. 2005. 105(8): 2999.

24. F. Jensen. Introduction to Computational Chemistry. John Wiley \& Sons. Odense 2007.

25. Saenger W., Lindner K. OH Clusters with Homodromic Circular Arrangement of Hydrogen Bonds. Angew. Chem. Int. Ed. 1980.19: 398-399.

26. Xantheas S.S. Cooperativity and hydrogen bonding network in water clusters. Chem. Phys. 2000. 258: 225-231.

27. Saenger W. Circular hydrogen bonds. // Nature. - 1979. 279: 343-344. 


\title{
ВЗАСМОДІЯ N-АЦЕТИЛНЕЙРАМІНОВОЇ КИСЛОТИ 3 ПОВЕРХНЕЮ КРЕМНЕЗЕМУ У ВОДНОМУ РОЗЧИНІ ЗА УЧАСТІ ВУГЛЕВОДІВ
}

\author{
Л. М. Ушакова, С. М. Дем'яненко, М. І. Терець, В. В. Лобанов, М. Т. Картель \\ Інститут хімії поверхні ім. О.О. Чуйка Національної академії наук України, \\ вул. Генерала Наумова, 17, Київ, 03164, Україна, е-таil: milushakova@gmail.com
}

Метою роботи є дослідження методом теорії функціоналу густини (обміннокорреляційний функиіонал В3LYP, базисний набір 6-31G(d,p) взаємодію $N$ ацетилнейрамінової кислоти (NANA) з поверхнею високодисперсного кремнезему (ВДК) за участі глюкози і сахарози у водному розчині на супермолекулярному рівні, тобто з явним врахуванням молекул води як розчинника.

Адсорбиія $N$-ацетилнейрамінової кислоти, а також окремо взятих вуглеводів (2люкозою і сахарозою) на гідратованій поверхні ВДК у водному розчині, розглядалась як процес заміщення молекул води на поверхні кремнезему молекулами адсорбатів.

Розглянуто дві схеми впливу молекули вуглеводу на адсорбиію $N$-ацетилнейрамінової кислоти. Згідно першої: взаємодія молекули NANA відбувається з комплексом кремнеземмоносахарид, згідно другої, відбувається взаємодія кластера кремнезему з комплексом NANA-моносахарид, де кремнезем зв'язується з комплексом через молекулу вуглеводу.

Результати аналізу розрахованих геометричних $i$ енергетичних характеристик свідчать, що адсорбиія на поверхні кремнезему з врахуванням гідратаиії термодинамічно ймовірна для молекули сахарози, незалежно від величини гідратуючого кластеру води (-33,0 та -24,5 кДж/моль). Молекула глюкози має позитивне значення (+9,8 та +2,7 кДж/моль), $\epsilon$ процесом невигідним з точки зору термодинаміки незалежно від розміру кластера води. Молекула $N$-ацетилнейрамінової кислоти має величину -1,3 кДж/моль для реакиї з n'ятьма молекулами води $i+0,9$ кДж/моль - з вісьмома молекулами води.

Встановлено, що у водному розчині наявність на поверхні кремнезему сахарози послаблює енергію гідратаиії (тобто відбувається легше заміщення молекулою $\mathrm{N}$ ацетилнейрамінової кислоти кластера води з поверхні модифікованого адсорбента), що в свою чергу сприяє адсорбиії NANA на поверхні кремнезему. Отже, схема 1 термодинамічно більш ймовірна ніж схема 2.

Це свідчить, що спостерігається взаємний вплив речовин в сумімі NANA 3 вуглеводами на взаємодію з кремнеземом в порівнянні із взаємодією речовин з кремнеземом окремо.

Ключові слова: поверхня кремнезему, адсорбиія $N$-ацетилнейрамінової кислоти, глюкоза, сахароза, супермолекулярне наближення, метод функціонала густини. 


\title{
ВЗАИМОДЕЙСТВИЕ N-АЦЕТИЛНЕЙРАМИНОВОЙ КИСЛОТЫ С ПОВЕРХНОСТЬЮ КРЕМНЕЗЕМА В ВОДНОМ РАСТВОРЕ ЗА УЧАСТИЕМ УГЛЕВОДОВ
}

\author{
Л. Н. Ушакова, Е. Н. Демьяненко, М. И. Терець, В. В. Лобанов, Н. Т. Картель
}

Институт химии поверхности им. О.О. Чуйка Наџиональной академии наук Украинь ул. Генерала Наумова, 17, Киев,03164, Украина, e-mail: milushakova@gmail.com

Целью работы являэться исследовать методом теории функиионала плотности (обменно-корреляцийный функционал B3LYP, базисный набор 6-31G(d,p) взаємодействие $N$ ацетилнейраминовой кислоты (NANA) с поверхностью высокодисперсного кремнезема (ВДК) за участием глюкозы и сахарозы в водном растворе на супермолекулярном уровне, то есть с явным учетом молекул воды как растворителя.

Адсорбция $N$-ацетилнейраминовой кислотьл, а также отдельно взятых углеводов (глюкозой и сахарозой) на гидратированной поверхности ВДК в водном растворе, рассматривалось как процесс замещения молекул воды на поверхности кремнезема молекулами адсорбатов.

Рассмотрено две схемь влияния молекуль углевода на адсорбцию $N$ ацетилнейраминовой кислотьл. Согласно первой: взаимодействие молекуль NANA происходит с комплексом кремнезем-моносахарид, согласно второй, происходит взаимодействие кластера кремнезема з комплексом NANA-моносахарид, где кремнезем связывается с комплексом через молекулу углевода.

Результаты анализа рассчитаных геометрических и енергетических характеристик говорят о том, что адсорбциия на поверхности кремнезема с учетом гидратации термодинамически вероятна для молекуль сахарозы, независимо от величины гидратирующего кластера воды (-33,0 и -24,5 кДж/моль). Молекула глюкозы имеет позитивное значение (+9,8 и +2,7 кДж/моль), является прочессом невигодным с точки зрения термодинамики независимо от размера кластера воды. Молекула $N$ ацетилнейраминовой кислоть имеет величину -1,3 кДж/моль для реакции с пятью молекулами воды и $+0,9$ кДж/моль - з восмью молекулами воды.

Установлено, что в водном растворе присутствие на поверхности кремнезема сахарозы ослабляет энергию гидратачии (то есть происходит легче замещения молекулой $N$-ацетилнейраминовой кислоты кластера воды с поверхности модифицированого адсорбента), что в свою очередь способствует адсорбичи NANA на поверхности кремнезема. Следовательно, схема 1 термодинамически более вероятна чем схема 2.

Это говорит о том, что наблюдается взаимное влияние вещество в смеси NANA c углеводами на взаимодействие с кремнеземом в сравнении с взаимодействием веществ $c$ кремнеземом отдельно.

Ключевые слова: поверхность высокодисперсного кремнезема, адсорбиия $N$ ацетилнейраминовой кислоть, глюкоза, сахароза, супермолекулярное приближение, метод функционала плотности. 